\title{
Global Generation(s) and Higher Education: Some Reflections on the Use of Ulrich Beck's Concepts in the Polish Context
}

\begin{abstract}
At the beginning of 21st century, we are witnessing a global transformation of the generational dynamics that exacerbate intra-generational tensions across ethnic lines. Amid crises, global challenges and deep-seated insecurity are interwoven with the turmoil of the present. With the instability of an increasingly complex world, young people are highly exposed to the forces of global risks. All young people are affected, but not all young people equally. Therefore, global generations break down into different fractions in a conflictual relationship with each other. This article outlines Beck's major concepts in order to show some theoretical frameworks for the study on global generations. The focus is on the role of the university that should play in the contemporary world. The example of Poland seems to be particularly relevant to the discussion about the validity of Beck's contribution to understanding of divisions, contradictions, and desires of the global generations. Many young Poles appear to be open for migratory experiences, but at the same time, they are reluctant to accept immigration to Poland. The article attempts to explore some contexts of mixed feelings about migration such as individuality and insecurity, media and the culture of catastrophe, education and neoliberal agenda. Nevertheless, the main goal of the article is to reconsider the role of education in times of rapid migration and generational interconnectedness.
\end{abstract}

\section{Keywords:}

young people, intra-generational conflicts, higher education, migration, U. Beck

1 Department of Basics of Pedagogy and Logopedics, Institute of Pedagogy, University of Zielona Góra, Poland, E-MAIL: M.Kowalski@ipp.uz.zgora.pl.

2 Department of Comparative Pedagogy, Institute of Educational Sciences, Pedagogical University of Cracow, Poland, E-MAIL: lukasz.albanski@up.krakow.pl. 


\section{INTRODUCTION}

The term of generation has been used in the sociological literature merely as a territorially bounded entity. Moreover, generations have been usually conceptualized as age-cohorts. These have limited the use of generation concepts to monolith-like categories with constant and passive identities (France, Roberts, 2015). Recently, however, sociologists have tried to introduce a new concept of generation. The return to generation as an interesting sociological category is related to the efforts made by sociologists to grasp the idea of social change in the twentieth first century from a global perspective (Beck, Beck-Gernsheim, 2009, Edmunds, Turner, 2005).

In his works, Ulrich Beck dealt with the notion of a global generation in relation to the trap of methodological nationalism (Beck, Beck-Gernsheim, 2009, Beck, 2016). According to him, under the impression of the national unity of state and education, many basic terms in the social sciences such as society, identity, inequality, or justice were vividly described as national (Beck, 2012, p. 55). As a result, both knowledge and education were limited to the framework conditions under which the nation state was still prevalent, but at a time when boundaries were muddled in a globalized world. In order to change that mindset, Beck and Beck-Gernsheim (2009, p. 25) claimed that social scientists needed a cosmopolitan outlook to understand the generational dynamics that exacerbate inter-generational tensions within nations and intra-generational affinities and conflicts between nations.

In this article, we suggested that, in times of rapid migration movements, when European societies face different scenarios of situations, in which are opposing ideas about national sovereignty and common future of the European Union, the understanding of the general dynamics of interethnic tensions within different units of global generation(s) seems to be particularly relevant to social sciences. The background of our article lies in Polish experiences. External migration in the context of current European situation has been merely exposed in the media as hazardous to the nation and the nation-building project. This belief is maintained by the majority of social survey respondents, which among them, the youngest participants (between 18 and 24) constitute the largest age group of opponents of external migration (above 80\%) (CBOS, 2017, p. 3). On the other hand, however, for an increasing number of young people, migration itself is seen as an option. The basic drive of migration for Poles is to find new life opportunities abroad. Therefore, we indicate in this article that the concept of global generations will offer an interesting insight into discussion about the modes of possible conflicts 
between different units of young people, relied on both commitment to mobility and structure of inequality.

\section{PROBLEMS OF GENERATION}

In the classical essay The Sociological Problem of Generations by Karl Mannheim (1997), for instance, the concept of generation implied transformative political power of utopia that people share with one another. Mannheim paid particular attention to the role of historical events in shaping a generational consciousness. Pierre Bourdieu (1990) demonstrated the significance of generational struggle over cultural resources as critical in cultural transformation. June Edmunds and Bryan S. Turner (2005, pp. 561-562) have argued that insights from both Mannheim and Bourdieu are important to understand the conditions under which generations become culturally or politically significant. However, they have also added that contemporary sociology needs to develop a new concept of global generations. To prove their point, Edmunds and Turner (2005, p. 566) have claimed that the global experiences of cultural traumas facilitated by the developments in new electronic communications have the potential for creating a global generational consciousness. The emergence of global generations is connected with the growth of communication across national boundaries and substantial increase in global interactivity.

As Arjun Appandurai (2000, p. 3) has demonstrated, the effects of the mass media spread across every continent and reach even seemingly remote places. Although the images conveyed in the media are not always true to reality, but full of fictions and myth, yet influence the life projects of ever more people in ever more places in the world. Appandurai (2000, p. 22) claims that "today imagination has become a social practice, in countless variants it is the engine for the shaping of the social life of many people in many different societies.” As a result, people no longer accept the incomparability of life chances based on national borders, but world society realities and possibilities impacted their own lives. The flows of information make their situations comparable, and in this way they are no longer determined by their modest surroundings, because they have learnt about the affluence of Europe.

Sociologists generally shared the view on modern society with one another that people get increasingly confused because what was unthinkable yesterday is possible and real today on the account of the fluidity of contemporary society (Albański, 2018). It challenges the way of being in the world and thinking about 
it. As Beck (2016, p. xi) embraced this idea in the preface to his book The Metamorphosis of the World, "a statement on which most people can agree, beyond all antagonism and across all continents, is: I don't understand the world anymore." He announced that insecurity turns into a key experience of social condition, transcending borders and human solidarity. The shared experience of insecurity conserve false paths in confronting people with a reality. The global media are full of pictures of imagined and real dangers.

According to Beck, the shock of global risks and crises radically affected the core of the self-conception of First Modernity with its basic premises of national and identity, or security and rationality (Beck, Sznaider, 2010, p. 381). Although the experience of generations might be increasingly globalized by media, the inequality of global situations produced sharp dividing lines and conflicts across ethnic divisions. However, the feeling of insecurity, which has become the trademark of the younger generations, was, in fact, neither local nor national circumstance. Therefore, Beck opposed the idea of social sciences isolated within national boundaries, mentioned it as historically out of date (Beck, Sznaider, 2010, p. 382). The combined phenomena of global mobility and inter-ethnic tensions show the conflict dynamics of a world society.

In a globalized world, the diversity and inequality of life chances all have become too visible. The expectations of human equality and migration dreams of a better life have driven people into external forms of mobility. On the other side of borders, however, growing insecurity turns into a key experience of many young people, which shatters their dream of well-being into pieces. Young people have to find their way in a market which is exposed to unpredictable forces and arbitrary rules. The condition of precariousness bears a deep mark on generational consciousness. Beck and Beck-Gernsheim (2009, pp. 25-26) suggested that, in order to describe the situations and positions of different units of younger in contemporary world risk society, a new concept of generational constellations needs to be embraced by the cross-border research on youth. Generational constellations represents the different sections of the conflicts dynamic of world society (Beck, Beck-Gernsheim 2009, p. 33). The prediction of generational constellations is conflict-laden: one unit of the global generation against the other.

\section{MIGRATION AND INDIVIDUAL RESPONSIBILITY}

In recent years, the topic of migration has featured significantly in public and political debates in Poland. The primary focus is on the emergence of a culture of 
migration in which spending a time working abroad becomes a normal rite of passage for young people. It leads to discontent with official adult standards that are seen as the hegemony of previous generations. Especially when the broken promises of a better life in the country have brought increasing alienation from official adult standards which promote both education and work (Albański, 2016).

The departure of young people of child-bearing age undoubtedly accelerate the speed at which the Polish society is ageing. Moreover, since many educated young people take their skills abroad, migration costs the additional brain drain damage (Iglicka, 2017). Although general concerns about migration and its impact on the future of Polish society are pressing, migration is also described in terms of possible human capital gaining, monetary and social remittances (Grabowska, Jaźwińska, 2015). The popular conception of migration overemphasizes what individuals can do, and the extent to which what they do is individually chosen rather than structurally determined. Young people show a tendency to downplay the existence of external obstacles as a factor, and make a more general argument that individual effort is all that is required for success. It rests on particular assumptions about themselves, seen to have choice and agency.

The idea of an individual that has the power to influence her or his life comes to determine a common understanding of human actions (Cybal-Michalska, 2012). It gives presumptions for treating migration as individual actions. It implies a tendency to define one's life situation in terms of individual responsibility and accountability (whilst dismissing certain social obstacles). Migration as a human experience always appeals to an individual sense of insecurity, comes as a result of moving into a new environment. Critical studies claim that the combination of experiencing persistent insecurity and regarding one's situation as a result of individual intervention could be indicated to be representative of the neoliberal subject (Foucault, 2008, Melosik, 2015, Potulicka 2011, Rose, 1999). The illusion of choice created by neoliberal self-conceptions masks the continued entrenchment of insecurity in the world. This is particularly problematic when those who lack cultural capital or other resources will increasingly be marginalized as risks accumulate in such a way as to strengthen existing patterns of inequality whilst those with adequate resources can gain safety and freedom from risk (Beck, 2016). Combined the experience of precariousness among the younger generations with the forces of migration can deepen the division between various generational fractions of young people in Europe. 


\section{LIVING IN A CATASTROPHE CULTURE ${ }^{3}$}

The current inclination of individuals and groups to react to the increasing insecurity in their lives by closing themselves down into tribes and erect imagined barriers and real walls against others could be strengthened by pictures. At the time of writing, news screens are dominated by images of migrants. The selection of images simply carries the message that the collective identities of Europeans are challenged in increasingly distressing ways. In Poland, a discourse of encroaching catastrophe has monopolized online comments. ${ }^{4}$ When migration is presented as a calamity, many details are unnoticed or separated from its historical roots that created the wave of migration, so that it comes to be interpreted as a dreadful accident. Such clarification of migration as an impending disaster mobilizes into a pattern that needs an emergency response but misses a thorough analysis.

Social theorists are very consistent with the idea that a retreat to a more fundamentalist politics of national homogeneity emerges from the insecurities and uncertainties that have increased with globalization (Agier, 2016, Bauman, 2016, Beck, 2016). Images of risk and danger to the nation are key factors that can be mobilized into demands to shut down the doors against strangers. Anti-immigration feelings in Europe have offered the breath of a new life to populist political parties. They give their voters a simple prescription for the complex situation: the quality of national homogeneity is essential for the sustenance of national unity. The nation is imagined as an ideal entity that should progress, be regulated, be made rational, and that should not be victimized by the rights of outsiders. In times of chaos, the political discourse of national unity, defined as it is in such a narrow way, shows its dark side. The precepts of rational interest and self-preservation flourish, because people are put into situations of believing they are threatened and endangered. Moreover, they believe that their vision of the nation is at risk, and the perception of a jeopardized nation is evident to support intolerance over charity.

Young people's devotion to life on a digital landscape can challenge them as citizens in a particular way. Although the web is usually described in terms of tremendous opportunities for information, social mobilization and action, some studies also show that when people are faced with a social problem, they are likely to seek only for the others with whom they agree. For instance, Sherry Turkle

3 Every channel, every day, the news is dominated by catastrophe. Therefore, everybody feels part of an emergency, but our attention is merely channeled into affiliating with a website or social media for comments (Turkle 2015: 299-301).

$4 \quad$ This is arguably significant in times when many young people describe their experience in dealing with news in this way that they learn something, get anxious and connect online. 
(2015) in her new book demonstrates how the use of digital technology trespasses on a time of discussion. In her view, getting online immunes young people from the real conflicts and solutions of the public square. Online, they can choose to see those who share their opinions and offer the ideas they think their followers want to be attached to. Therefore, she warns that a growing tendency among young people for the participation in a close-knit online communities will carry high social costs such as a loss of empathy for other people's situations and a growth of narrow-mindedness (Turkle, 2015, p. 41).

The digital availability of learning other voices does not enable people to see the world through the lenses of diversity. The diversity and inequality of life chances become all visible thanks to global media, but that is exactly what produces particular tensions and potential conflicts. The affective meaning of us is a fundamentally structuring social force, while the opposite side of otherness is powerful to see a sharp distinction: who are they, and why are they here? What has been already manifested as the migrant crisis will emerge more dramatically as a global redistribution struggle of poverty and wealth.

The growth of global communications technology has accelerated the process of increasing interactivity across national boundaries that created the emergence of global consciousness (Robertson, 2011). The emergence of which has its global consequences, but it does not promote the sense of connection, nor a solidarity of feeling and meaning. Even though electronic communications technology has enabled traumatic events of migration to be experienced globally, national solidarity remains a primary focus of collective feeling and meaning. The differentiation is created in response to the same event of migrant crisis, but people react quite differently depending on their spatial location. Everyone is galvanized by the shared sense of crisis, albeit from different angles and allegiances. It generates the divide between the worlds of external migrants and territorially bound residents who are barricading themselves behind their national worldviews. As many people have found themselves confronted by the tsunami of migration issues in the media, the experience of living in a catastrophe culture is the result.

Media coverage shows the systematic demonization of migrants, whose motives for coming to Europe are routinely seen as suspect or illegitimate (Crowley, Skeparis, 2018). The promotion of human rights, which once used to be made Europeans open for the rest of the world, nowadays, is named as a fatal error of cosmopolitan elites who are accused of short-slightness for their actions that caused the loss of control over migration flows. Migration is believed to seal the future of European project and to sound the retreat to nationalistic sentiments. There is the claim that only the return to closed national borders would stop the 
encroaching catastrophe of migration. On the contrary to this, the migrant crisis shows that external boundaries do not work as an impermeable membrane which is supposed to prevent outsiders from entering European societies.

\section{EDUCATION}

Higher education is usually described in terms of the social process of enlightenment. It means that higher education provides knowledge about the contemporary world and promotes understanding of its complexity. Moreover, it means that higher education is the process of making students understand the rising forces of global interdependence. However, the national model of the university makes the mission of higher education very ambivalent. Beck (2012, p. 59) accused the national model of the university of getting too deeply rooted in methodological nationalism. He explained that global problems create transnational interdependence, but the university inculcates the national outlook in societies. It helps methodological nationalism contribute to the belief in the power of nation-state and externally set boundaries in dealing with global insecurities. The logical conclusion of contemporary trends around the world takes people back to a world of weakening social bonds, globalization of indifference and tribalism. The lifting of human solidarity to the level in which equality has been promised for all is likely to be claimed as a Sisyphean task. On the contrary to this, Beck perceived human solidarity as a precondition of survival against global challenges. According to him, the emancipatory power of education will create an entirely different way of conceptualizing the world and chances of survival within it (Beck 2012, p. 59).

The role of the university that should play in the changed world is shattered into pieces because of its general turn into a corporate management (Milliken, Colohan, 2004). The change has come as a result of introducing more and more vocational training into university programs. The university become diploma mills and higher education is evaluated according to an access to well-paid jobs. Many young people demand more education as perceived remedy for experienced uncertainty. However, there is no obvious connection that education can provide a ticket for a decent life. Even worse, the faith in the vocational policy premised on the human capital dictate has broken the edge of social sciences (Albański, 2016). The belief that higher education can set people free from the confines of ignorance, has been changed into the single-minded pursuit for credentials. The marketization of social sciences reiterates a nightmare of Weberian iron cage of rationalization, in 
which the contemporary university is in the service of an economic order with all the related technical requirements of machine production.

The rise of neoliberalism means the foregrounding of individual responsibility and the concomitant weakening of social solidarity (Bourdieu, 1998). In the realms of higher education, the rise of neoliberal policies demonstrates the privatization of risk and the logic of market fundamentalism associated with human capital investments (Gromkowska-Melosik, 2016). The mission of university to provide a liberal education that contributes to the production of a citizenry that is capable of being engaged in value-based discussions has been negated in favor of vocational policies. In principle, the market logic is associated with a movement toward the use of meritocratic standards and the idea of education as human capital investment constitutes the litmus test for meritocratic rule in societies (Becker, 1964). Defined as serving in the needs of economy, higher education favors increased competition and self-interest over social responsibility and intellectual engagement. Competition heightens the sense of individual position and may lead to entrenchment into different social divisions. Simultaneously, the erosion of the welfare state and the flexibility of employee contracts increase economic insecurity, which may undermine solidarity and trigger resentment projected at others. Moreover, the links between education and work seem to have become less obvious and powerful as young people come into adulthood which involves a wide variety of routes, many of which appear to have uncertain outcomes (Melosik, 2013). The gap between opportunity structures and self-reliance is a constant source of frustration and stress for today's youth. The forces of social anger can be channeled into decline in solidarity, narrower definitions of social membership (focused on individual responsibility for risk and social position), and stronger boundaries toward the poor and the stranger.

According to Beck (2012, pp. 56-57), the combination of experiencing insecurity and regarding one's situation through the lens of a free choice to shape individual achievement or failure is a part of the dominant discourse on youth, education and unemployment that positioned young people in charge of their personal situation. The neoliberal agenda on universities and youth unemployment, linked together with the pressure of globalization and selfish individuality will help the return of a tribal attitude and indifference toward global inequalities. The social Darwinian ideas of survival of the fittest will prevail over intellectual and social virtues (Beck, 2012). With the contemporary insecurity of the world and the anxiety of individualized lives, the return to such radical ideas seems to be increasingly accepted as rational. The precepts of rational interest flourish with significant consequences for the position of the stranger. Young people are put into 
situations of believing they are threatened and endangered by strangers. At best they believed that they owe them nothing. The illusion of self-rationality is merely used to play with identity in this way, which excludes others from their dignity and entitlement to human rights.

Beck (2012, p. 57) tried to warn that what is truly toxic is that the neoliberal agenda on higher education not only gives the overt justification to indifference towards global inequalities and human misfortunes, but also severely limits the capacity for understanding, how people conceive of reality. In addition to the concomitant diffusion of neoliberal discourse and ideology in education, Beck (2016, p. 6) persuaded that the national frame of reference blinded people to see broad potential effects of the rise of global risks and insecurities. In his view, the purpose of the university is to sharpen own ideas through the confrontation with the world of global threats such as economic and migration crises, poverty, terrorism, and inequality (Beck, 2012, p. 59). Focused on its self-centeredness, the national model of the university can lose sight of the complete picture of the world. The globalized reality constitutes everybody's strategic lived reality. People are interlinked with communications technology, migratory experiences, transnational corporations, etc., which means that they all are affected by global risks in one way or another.

Although Beck seemed to be very skeptical about the national model of the university, he strongly believed in the role of the university that could play in the process of awakening the global consciousness of the world. Beck (2012, p. 56) recommended the university of world citizenship, which would broaden a general outlook on globality and (human) social life on planet Earth. He believed that the social lexicon could be rewritten accordingly to grasp global variability and global interconnectedness. The mission of the university is to show that, on the contrary to popular views that the sources of chaos and current problems lie in an outside world, in the contemporary world of insecurity and unpredictability, nobody can solve their problem on their own, because global problems create transnational interdependency. It means that graduates from the university will get a better understanding of possible tensions within global generations and it can counteract the dichotomous cleavage between different conflict-laden units of young people.

\section{CONCLUSIONS: HIGHER EDUCATION IN THE GLOBAL AGE}

Higher education is perceived as one of the solid foundations of civic society. However, the spread of neoliberal policies in education has altered the meaning of 
social life. Consequently, the social impulse towards higher education appeals to individual aspirations of the privatization of wellbeing. The promotion of indifference to other people could be an engine of dangerous trends, which legitimates zero-sum game visions of contemporary society. Specifically, it helps reshuffle social boundaries in ways that narrow definitions of solidarity and further rationalize into the proof that some categories of people need to be less entitled to human rights and welfare. Moreover, according to Beck (2012, p. 55), the national model of the university puts young people caged in the vision of a sanctimonious national autistic world with its fear of the outsider. Focused on the notion of global generation(s), he predicted that territorially bounded thinking of young people would accelerate the conflict-laden interaction model, which based on the emergence of intra-generational affinities and tensions (Beck, Beck-Gernsheim, 2009). Combined forces of mobility and insecurity have far-reaching consequences for divisions, contradictions, and desires of the global generations. Hopes and dreams about a better life are confronted with the contemporary insecurity of individualized lives. On the one side, there are the fears of chronic youth unemployment and blocking opportunities for socio-economic strides, and on the other, there is an existence in poverty without improving life chances. The feeling of deprivation among young people has become an almost universal feature.

The global flows of information and picture make inequality of opportunities apparent (Appadurai, 2000). The images of affluence forcefully drive people into migration against the politics of imagined barriers and real walls. The illusion of barricading behind walls and boundaries does not do justice to the complexity of the world. Beck (2012, p. 56) called for a more-cosmopolitan outlook to understand the changing conditions in the world and a university as the school of world citizenship. The cosmopolitan model of the university could offer explanations and solutions, which reveal the possibility of living people together and cooperating with one another, alternative for the construction of a better future, in response to a Hobbesian world of growing insecurity and violence. The change in education implies a complete transformation into a different reality, into seeing the world and other people differently.

The case of young Poles seems to be a very interesting example for the discussion about cross borders relations within the frameworks of global generations. On the one hand, the migration of young Poles is often associated with both individual aspirations and structural constrains, on the other, Poland was a source of emigration and only recently began considering as a country of receiving. An abrupt increase in immigration may be perceived conspicuous by the majority of young Poles, who declare that they do not want to open their country for migrants. These 
perceptions may be reinforced by economic insecurity as well. Such observations are only a preliminary step toward a detailed discussion about young Poles in the context of the generational dynamics that exacerbate intra-generational tensions across national borders.

The national-territorial remains the primary container for the analysis of the process of education. The idea of belonging is thus entertained in an asymmetrical manner. Crossing borders offers opportunities to live and work abroad, yet binding identity and borders together is the preferred means of national identification. The omnipotence of the state in higher education, and in the humanities and social sciences in particular, is unquestioned (Beck 2012). In an internationally competitive marketplace, higher education plays a crucial role in helping each nation to create a cutting edge. In respect to the national model of the university and the globalization discourse, attempts are made to conform educational values and provisions to the needs of capital and economy. In Poland, awareness of international comparisons (such as PISA/OECD) has been implemented into a package of reforms to raise the measurable levels of attainment (Śliwerski, 2018). As a result of reforms emerged a set of public policy demands for effectiveness, accountability and efficiency. However, the politics of effectiveness and its influence on education policy is often produced out of the complexity of the world and civic virtues.

Therefore, there is a pertinent question, whether education is part of solution, or offers delusive ideas in the changed world. In response to a world defined by its endemic instability and incompleteness, the emergence of visions of the future generations could set trapped in a new form of tribalism. As it will happen, it bears all the hallmarks of Beck's scenario of intergenerational tensions and conflicts. Nonetheless, education makes the point of references for a better world. The emancipatory potential of education opens up new perspectives on the ways in which relationships between globalization and education policy continue to evolve, because education (and critically oriented humanistic and social sciences in particular) contains a sort of navigation system for the fast-changing world. In order to grasp this idea, however, as Bogusław Śliwerski (2018, p. 161) forcefully argues is that "what seems necessary is breaking the consensus machinery to stop citizens' indifference.” It means that people need to recognize that they have been subjected to horrendous events that violate the norms of human dignity and sovereignty. Beck (2016, p. 5) believed that global risk would create a cosmopolitan moment. In other words, that moment would bring a social catharsis that break downs mental barriers of national worldview and unlocks the potential for all sorts of normative expectations and developments, which provide global perspectives on human actions. The role of the university could not be limited to globally 
recognized diplomas and rankings, but contributes to creating a global consciousness. After all, we want higher education that offers explanations and solutions, and last but not least, education that will not be indifferent to people, and about our common future as humankind.

\section{References}

Agier, M. (2016). Borderlands: Towards an Anthropology of the Cosmopolitan Condition. Cambridge, Malden: Polity Press.

Albański, Ł. (2018). The Metamorphosis of the World and Nostalgia for an Ideal Past, International Sociology (prepared for print).

Albański, Ł. (2016). Higher Education and the Growth of Menial Jobs, Problems of Education in 21st Century, 70, pp. 8-20.

Appadurai, A. (2000). Grassroots Globalization and the Research Imagination, Public Culture, 1(12), pp. 1-19.

Bauman, Z. (2016). Strangers at Our Door. Cambridge, Malden: Polity Press.

Beck, U. (2016). The Metamorphosis of the World. Cambridge, Malden: Polity Press.

Beck, U. (2012). The Return of Social Darwinism or: Which University Do We Want?. In: U. Beck, Twenty Observations on a World in Turmoil (pp. 53-59). Cambridge, Malden: Polity Press.

Beck, U., \& Sznaider, N. (2010). Unpacking Cosmopolitanism for the Social Sciences: A Research Agenda, The British Journal of Sociology, 1 (61), pp. 381-403.

Beck, U., \& Beck-Gernsheim E. (2009). Global Generations and the Trap of Methodological Nationalism for a Cosmopolitan Turn in the Sociology of Youth and Generation, European Sociological Review, 1(25), pp. 25-36.

Becker, G.S. (1964). Human Capital: A Theoretical Analysis with Special Reference to Education. New York: Columbia University Press.

Bourdieu, P. (1998). Acts of Resistance: Against the Tyranny of the Market. New York: New Press.

Bourdieu, P. (1990). “Youth” Is Just a Word. In: P. Bourdieu, Sociology in Question (pp. 94102). London: Sage.

CBOS (2017). Stosunek do przyjmowania uchodźców. Komunikat z badań nr 44 z kwietnia. Retrived from http://www.cbos.pl/SPISKOM.POL/2017/K_044_17.PDF (accessed: September 20, 2018).

Crawley, H., \& Skleparis, D. (2018). Refugees, Migrants, Neither, Both: Categorical Fetishism and the Politics of Bounding in Europe's 'Migration Crisis', Journal of Ethnic and Migration Studies, 1 (44), pp. 48-64, DOI: 10.1080/1369183X.2017.1348224.

Cybal-Michalska, A. (2012). Kariera jako „własność” jednostki - rozważania teoretyczne nad definicyjnym credo, Kultura-Społeczeństwo-Edukacja, 1 (17), pp. 193-203.

Edmunds, J., \& Turner, B.J. (2005). Global Generations: Social Change in the Twentieth Century, The British Journal of Sociology, 4 (56), pp. 559-577.

Foucault, M. (2008). The Birth of Biopolitics. Basingstoke: Palgrave Macmillan. 
France, A., \& Roberts, S. (2015). The Problem of Social Generations: A Critique of the New Emerging Orthodoxy in Youth Studies, Journal of Youth Studies, 2 (18), pp. 215-230, DOI: 10.1080/13676261.2014.944122.

Grabowska, I., \& Jaźwińska, E. (2015). Migracje poakcesyjne Polaków i kapitał ludzki: transfer wiedzy, umiejętności, kompetencji, Studia Migracyjne - Przegląd Polonijny, 2 (156), pp. 53-80.

Gromkowska-Melosik, A. (2016). Jednostka, neoliberalizm i redukcjonizm edukacji współczesnej, Studia Edukacyjne, 41, pp. 107-115, DOI: 10.14746/se.2016.41.7.

Iglicka, K. (2017). Państwo polskie wobec wyzwań demograficznych: strategia i instrumenty polityki społecznej oraz gospodarczej, Polityka Społeczna, 3 (516), pp. 1-4.

Mannheim, K. (1997). The Sociological Problem of Generations. In: Collected Works of Karl Mannheim (pp. 163-195). London: Routledge.

Melosik, Z. (2015). Neurotyczna tożsamość w społeczeństwie neoliberalnym, Studia Edukacyjne, 37, pp. 77-90.

Melosik, Z. (2013). Edukacja uniwersytecka i procesy stratyfikacji społecznej, KulturaSpołeczeństwo-Edukacja, 1 (3), pp. 21-46.

Milliken, J., Colohan, G. (2004). Quality or Control? Management in Higher Education, Journal of Higher Education Policy and Management, 3 (26), pp. 381-391.

Potulicka, E. (2011). Teoretyczne podstawy neoliberalizmu a jego praktyka, Przegląd Pedagogiczny, 1, pp. 234-257.

Robertson, R. (2011). Global Connectivity and Global Consciousness, American Behavioral Scientist, 10 (55), pp. 1336-1345.

Rose, N. (1999). Governing the Soul. The Shaping of the Private Self. London: Free Association Books.

Śliwerski, B. (2018). The Polish Educational Policy after 28 Years of Political Transformation, The New Educational Review, 2 (52), pp. 149-163.

Turkle, S. (2015). Reclaiming Conversation: The Power of Talk in a Digital Age. New York: Penguin Random House. 